Copyright $\odot$ SAGE Publications 2008 (Los Angeles, London, New Delhi and Signapore) 1468-7968 Vol 8(2): 251-283; 087023

DOI: $10.1177 / 1468796807087023$

http://etn.sagepub.com

\title{
Review Symposium: Multicultural Odysseys: Navigating the New International Politics of Diversity by Will Kymlicka (published 2007). Oxford: Oxford University Press. ISBN 978-0-928040-7
}

\section{The global odysseys of liberal multiculturalism}

\author{
RAINER BAUBÖCK \\ European University Institute, Italy
}

Will Kymlicka is certainly one of the most prolific and influential political theorists of our time. In contrast with the title of his new book, his own thought has travelled a remarkably straight path. He started his publishing career by engaging with mainstream liberal theories of justice and their communitarian critics and proposing that cultural minority rights can be defended from a perspective of comprehensive philosophical liberalism (Kymlicka, 1989). In probably his best-known book, on 'multicultural citizenship' (1995), he started instead with examining how western liberal democracies accommodate minority claims through granting polyethnic rights, special representation and self-government. In this text, the philosophical arguments are only elaborated later as a justification or critical benchmark for existing institutional arrangements. Kymlicka's next monograph (1998) applied this analytical frame to his native Canada, which was the first country to declare itself officially a multicultural state in 1971. In the 1990s, Kymlicka's ideas were widely discussed, not only by political philosophers, but also by empirical social scientists. Their main critique was that he had merely theorized the Canadian model without taking into account the quite different regional contexts in other parts of the world. He confronted this charge in a book on Central and Eastern Europe that raised the question 
Can Liberal Pluralism be Exported? (Kymlicka and Opalski, 2002). In this particular volume, Kymlicka defended the normative desirability of liberal multiculturalism, but conceded that such arrangements might be much harder to achieve in newly established or restored nation states where ethnic minorities are perceived as threats to sovereignty and state security.

Multicultural Odysseys (2007) seems to complete this agenda of normative defence and contextual specification. After travelling round the globe from northern America via Eastern Europe to Africa (Berman et al., 2004) and Asia (Kymlicka and He, 2005), Kymlicka visits now international organizations and international law. In stark contrast with the optimistic tone of his earlier work, his diagnosis is now much gloomier. Driven by fears about a pandemic spread of ethnic violence after the break-up of Yugoslavia and the Soviet Union, but also inspired by the successful accommodation of homeland minorities in Canada and western Europe, international organizations and lawyers have since the early 1990s embraced liberal multiculturalism. Yet the instruments they have developed to promote it are, in Kymlicka's eyes, 'morally inconsistent, conceptually unstable, and politically unsustainable'. He believes that there is a need for international norms and agencies that promote liberal multiculturalism, but he fears that the current framework is more likely to result in retreat.

Kymlicka has two distinct concerns. The first is that in many parts of the world the political conditions that have allowed liberal multiculturalism to become accepted may be absent. Among these conditions, he counts the desecuritization of conflicts over minority demands within and across international borders, and a broad inter-ethnic consensus on human rights that reduces fears of dominant groups that minorities will abuse their liberties and autonomies. The second concern is about a tension between the international community's commitments to justice and to state security. This tension has distorted the codification of minority rights whenever they were seen as potentially endangering the territorial integrity of states. On the one hand, with few exceptions, the relevant international legal documents have merely codified individual human rights that do not address demands of homeland minorities for their own institutions of government, higher education or control over natural resources. Interventions by international organizations, on the other hand, have selectively targeted conflicts with high levels of actual or potential violence and have thereby rewarded minority belligerence and government intransigence through political recognition and economic incentives.

In Multicultural Odysseys, Kymlicka analyses these tensions in two case studies: first, European attempts, focused on the 1995 Council of Europe Framework Convention on National Minorities and the Organization for Security and Co-operation in Europe's (OSCE) High Commissioner on National Minorities established in 1992, to promote a liberal accommodation of national and linguistic minority claims in the post-communist 
states of the continent, and, second, United Nations (UN) efforts to codify the rights of indigenous peoples. While the European approach may have contained the further spread of violent conflict, it has not succeeded in promoting devolution and regional autonomy as responses to the demands of ethno-national territorial groups.

The career of indigenous peoples' claims, which culminated in the longdelayed adoption of the UN Declaration on their rights in September 2007, provides a much stronger case for the global spread of collective minority rights. Yet, in Kymlicka's view, this very success may contain the seeds of its own undoing. Since only indigenous people are now recognized as having claims to self-determination and control over natural resources, other minorities have strong incentives to claim indigeneity and states have reasons to act preventively against mobilizations for such demands.

In the conclusions of Multicultural Odysseys, Kymlicka sketches possible responses to these dilemmas. Where conditions for the full spectrum of minority rights that have been accepted in western democracies are absent, a sequencing of such rights may be necessary, so that regimes in transition to democracy are not over-burdened with expectations of immediate and full compliance with a comprehensive rights catalogue, while minorities can be assured that patience will eventually be rewarded with an expanded scope of powers and rights. In order to avoid the perverse incentives of an approach that targets only particular categories such as Europe's national minorities or indigenous peoples in white settler states, Kymlicka suggests a multitargeting strategy that would specify rights for all major types of minorities.

Kymlicka's book does not elaborate fully such alternative strategies and remains rather sceptical about their political feasibility. Instead, he opens a debate about how international law and organizations could respond to cultural diversity in a more consistent and progressive way. The contributions in this review symposium ${ }^{1}$ accept this challenge but also question many of the premises underlying Kymlicka's approach. Multicultural Odysseys describes the uncertain destiny of liberal pluralism in the international arena, but it is also a station in its author's intellectual journey that is not yet Ithaca.

\section{Notes}

1 Draft versions of these contributions were presented at a conference on Kymlicka's book in May 2007 at the European University Institute in Florence, Italy.

\section{References}

Berman, Bruce, Dickson Eyoh and Will Kymlicka (eds) (2004) Ethnicity and Democracy in Africa. London: James Currey Publishers and Athens, OH: Ohio University Press.

Kymlicka, Will (1989) Liberalism, Community and Culture. Oxford: Oxford University Press. 
Kymlicka, Will (1995) Multicultural Citizenship: A Liberal Theory of Minority Rights. Oxford: Oxford University Press.

Kymlicka, Will (1998) Finding Our Way: Rethinking Ethnocultural Relations in Canada. Oxford: Oxford University Press.

Kymlicka, Will (2007) Multicultural Odysseys. The New International Politics of Diversity. Oxford: Oxford University Press.

Kymlicka, Will and Baogang He (eds) (2005) Multiculturalism in Asia. Oxford: Oxford University Press.

Kymlicka, Will and Magda Opalski (eds) (2002) Can Liberal Pluralism be Exported? Western Political Theory and Ethnic Relations in Eastern Europe. Oxford: Oxford University Press.

RAINER BAUBÖCK is Professor of social and political theory at the European University Institute, Italy. Address: European University Institute,via dei Roccettini, 9, I-50014 San Domenico di Fiesole (FI), Italy. [email: rainer.baubock@eui.eu]

\section{The left-Herderian ontology of multiculturalism}

\section{ANDREAS WIMMER}

The University of California, Los Angeles

Will Kymlicka's new book moves away from the normative tradition of reasoning, to which his earlier work has made well known and widely respected contributions, towards a more empirically oriented perspective informed by political science and political sociology. The book describes the major historical events and organizational channels through which liberal multiculturalism has come to influence major international policymaking bodies, what the experiences with putting multiculturalism into practice have been in North American and Europe, and why the global spread of multiculturalism has come to a halt before having had any impact on the reality of ethnic exclusion in Africa, Asia and the Middle East.

Why has the multicultural revolution stalled? Kymlicka's answer is based on a thorough review of the empirical literature and stands out for its nuanced and balanced nature. But the author seems to shy away from drawing the full consequences of his own analysis as. The disjuncture between analysis and conclusion emerges, I will argue because the book has 